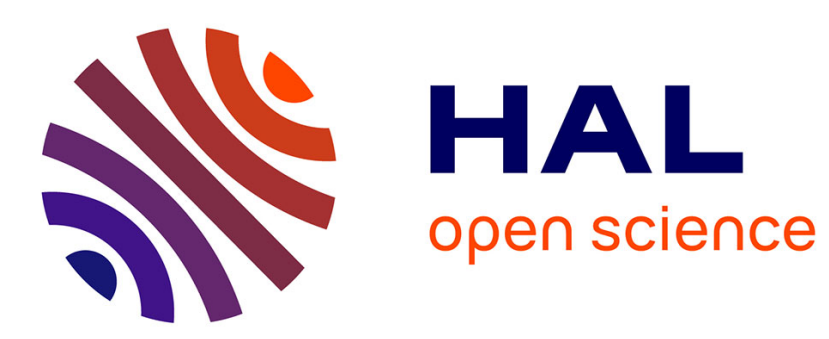

\title{
Phonons-defects interactions in CdTe
}

J.L. Tissot, P.L. Vuillermoz, A. Laugier

\section{To cite this version:}

J.L. Tissot, P.L. Vuillermoz, A. Laugier. Phonons-defects interactions in CdTe. Revue de Physique Appliquée, 1977, 12 (2), pp.267-272. 10.1051/rphysap:01977001202026700 . jpa-00244157

\section{HAL Id: jpa-00244157 https://hal.science/jpa-00244157}

Submitted on 1 Jan 1977

HAL is a multi-disciplinary open access archive for the deposit and dissemination of scientific research documents, whether they are published or not. The documents may come from teaching and research institutions in France or abroad, or from public or private research centers.
L'archive ouverte pluridisciplinaire HAL, est destinée au dépôt et à la diffusion de documents scientifiques de niveau recherche, publiés ou non, émanant des établissements d'enseignement et de recherche français ou étrangers, des laboratoires publics ou privés. 


\title{
PHONONS-DEFECTS INTERACTIONS IN CdTe
}

\author{
J. L. TISSOT, P. L. VUILLERMOZ and A. LAUGIER \\ Laboratoire de Physique de la Matière (*), Institut National des Sciences Appliquées de Lyon, \\ 20, Avenue Albert Einstein, 69621 Villeurbanne Cedex, France
}

\begin{abstract}
Résumé. - Les défauts électriquement inactifs dans CdTe ont été mis en évidence par deux méthodes :

- conductivité thermique à basse température,

- topographie X.

Dans tous les matériaux étudiés, créés par T. H. M. ou fusion de zone, non dopés, dopés au chlore et à l'indium, des microprécipités ont pu être étudiés. Leur concentration, déduite des mesures de conductivité thermique par un calcul basé sur la méthode de Callaway, est comprise entre $10^{14}$ et $10^{15} \mathrm{~cm}^{-3}$ et leur diamètre moyen supérieur ou égal à $100 \AA$. Cette concentration est indépendante du taux de dopage et de la méthode d'élaboration. Des précipités beaucoup plus grands $(1 \mu \mathrm{m})$ apparaissent en topographie $X$ sur les cristaux non dopés et purifiés par fusion de zone ainsi que sur les matériaux dopés au chlore. Il n'y a pas de corrélation entre ces défauts et les microprécipités.
\end{abstract}

\begin{abstract}
A study of electrically inactive defects has been performed on CdTe single crystals by two different experimental techniques:

- the low temperature thermal conductivity measurement. It has been used as a tool to study crystal defects, such as clusters, stacking faults or point defects ;

- the $\mathrm{X}$ ray topography. It completes the first method in showing large aggregates (resolution $\simeq 1 \mu \mathrm{m}$ ), dislocation arrays or structural defects.

The following observations regarding the experimental results are worth noting. CdTe crystals (undoped, $\mathrm{Cl}$ or In doped) have been grown by melting zone or THM. Microprecipitates are found in all CdTe crystals. The concentration varies from $10^{14}$ up to $10^{15} \mathrm{~cm}^{-3}$ and the mean diameter reaches $100 \AA$ or more. This concentration is independant on the doping level and on the crystal growth process. The presence of such a precipitation is probably associated with the chemical and thermal growth conditions of the crystals. The $K(T)$ curves fit by the Callaway phenomenological model indicates a point defect concentration of about $10^{18} \mathrm{~cm}^{-3}$. The isotopical mass deviation introduces only a concentration of $7 \times 10^{17} \mathrm{~cm}^{-3}$. The excess is ascribed to several origins such as nonstoichiometry in $\mathrm{CdTe}$, doping, chemical impurities or $V_{\mathbf{C d}}$. In $\mathrm{X}$-ray topography large precipitates appear only in crystals not intentionally doped and melting zone purified, or in $\mathrm{CdTe}: \mathrm{Cl}$. No correlation is found between large and micro precipitates. Dislocations with atmosphere appear also with a low concentration of about $10^{4} \mathrm{~cm}^{-2}$.
\end{abstract}

1. Introduction. - The study of the thermal conductivity of CdTe at low temperature has been pursued by different authors as Holland [1] and Slack [2, 3]. Slack analyses the influence of phonon scattering by magnetic impurities on thermal conductivity. On the other hand, electrical measurement results show a strong correlation between electrical properties and elaboration methods. In order to find or not such a correlation with nonactive electrical defects, we have measured the thermal conductivity of different specimens produced by :

- vertical zone melting technique,

- modified Bridgmann technique,

- Travel Heater Method (T. H. M.).

The interpretation of our experimental results is made with the Callaway phenomenological model.

(*) Equipe de recherche associée au C.N.R.S.
2. Experiments. - The experimental apparatus of thermal conductivity measurements was described in several publications $[4,5,6]$. It is a comparative method which allows the use of small dimension samples.

The measurements are performed between $1.4 \mathrm{~K}$ to $300 \mathrm{~K}$, the relative incertitude is about $1 \%$ to $3 \%$ for temperature and lower than $10 \%$ for thermal conductivity. Our samples are separated in two groups :

- the first group concerns specimens the elaboration of which involves fusion of the material,

- the elaboration of specimens of the second group is performed at a temperature lower than the melting point of $\mathrm{CdTe}$.

Experimental results are shown figure 1 (first group) and figure 2 (second group). The curves for all the specimens are comparable, they show a maxi- 


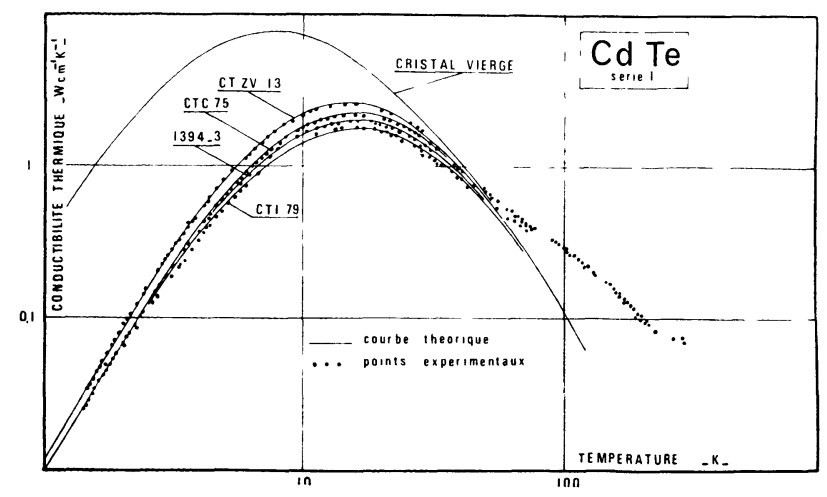

FIG. 1. - Thermal conductivity of first group samples.

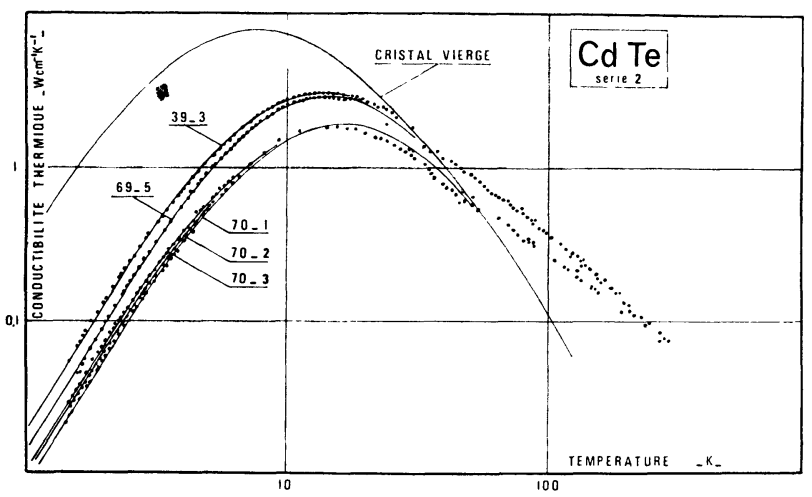

Fig. 2. - Thermal conductivity of second group samples.

mum value of thermal conductivity of $1.5 \mathrm{~W} . \mathrm{cm}^{-1} \mathrm{~K}^{-1}$ to $3 \mathrm{~W} \cdot \mathrm{cm}^{-1} \mathrm{~K}^{-1}$ at a temperature of about $14 \mathrm{~K}$ to $17 \mathrm{~K}$. The thermal conductivity becomes proportionnal to $T^{3}$ under $2 \mathrm{~K}$. In the figures, the solid lines are the Callaway model fits.

3. Analysis. - 3.1 Model. - We have carried out a quantitative analysis of our thermal conductivity data with the Callaway model [7] which is now well established by many investigators such as Nettleton [8] and Berman and Brock [9]. This model uses a Debye spectrum as dispersion curve and involves also the additivity of the inverse of independant relaxation times. A difficulty in the theoretical analysis of thermal conductivity is the determination of the relaxation times $\tau$ of the respective phonon scattering processes. The total relaxation rate $\tau_{\text {tot }}$ used in the Callaway formalism is :

$$
\tau_{\mathrm{tot}}^{-1}=\sum_{i=1}^{n} \tau_{i}^{-1}
$$

Phonon scattering processes are well known and we consider consecutively :

\subsubsection{Boundary phonon scattering}

$$
\tau_{1}^{-1}=\frac{v}{L^{\prime}}
$$

when $L^{\prime}$ is Casimir's length. For samples of square cross section $L^{\prime}=1.12\left(l_{1} \cdot l_{2}\right)^{1 / 2}, l_{1}$ and $l_{2}$ are lateral dimensions. $v$ : mean sound velocity.

3.1.2 Phonon scattering by point defects. - The phonon scattering cross section of point defects can be calculated from Klemens' formula [10] :

$$
\tau_{2}^{-1}=A \omega^{4}
$$

where

$$
A=\frac{3 V_{0} \Gamma}{\pi v^{3}}
$$

$V_{0}:$ volume of elementary cell,

$\Gamma$ : point defect scattering parameter.

For an atomic impurity $X$, we have :

$$
\Gamma(X)=C \sum_{i} f_{i}\left(\frac{m_{i}-m_{x}}{m_{x}}\right)^{2}
$$

where

$$
m_{x}=\sum_{i} f_{i} m_{i}
$$

$f_{i}$ is the fractional concentration of the $i$-th isotope of mass $m_{t}$ of the impurity $X$;

$C$ is a constant. $C=1 / 12$ for $X$ low concentration.

For a compound $X_{x} Y_{y}, \Gamma(X, Y)$ is given by:

$$
\Gamma(X, Y)=\frac{x}{x+y}\left(\frac{m_{x}}{\bar{m}}\right)^{2} \Gamma(X)+\frac{y}{x+y}\left(\frac{m_{y}}{\bar{m}}\right)^{2} \Gamma(Y)
$$

where :

$$
\bar{m}=\frac{x m_{x}+y m_{y}}{x+y} .
$$

We may consider this compound as a monoatomic material of average mass $\bar{m}$ and of unit cell average volume $V$, because at a temperature lower than $\theta_{\mathrm{D}} / 10$ all the atoms of one cell vibrate with the same phase.

\subsubsection{Phonon-phonon interaction. - The Callaway} model involves :

$$
\tau_{3}^{-1}=B \omega^{2} T^{3}
$$

where $B$ : anharmonic parameter.

3.1.4 Phonon scattering by clusters. - Two limiting cases are well defined :

- if the size « $a$ » of the spherical clusters is much smaller than the inverse of phonon momentum $q$, then they act as Rayleigh scatterers and the effective scattering cross section is proportional to $\omega^{4}$,

- in the other case, where " $a$ » is much greater than the inverse of phonon momentum, the effective scattering cross section will be independant of the 
phonon frequency and proportional to the geometrical cross-section :

$$
\begin{aligned}
\tau_{4}^{-1}=\frac{1}{4} S \pi \frac{a^{6} \omega^{4}}{v^{3}} & (\text { for } q a \ll 1) \\
\tau_{4}^{-1}=\frac{1}{4} S \pi a^{2} v & (\text { for } q a \gg 1) .
\end{aligned}
$$

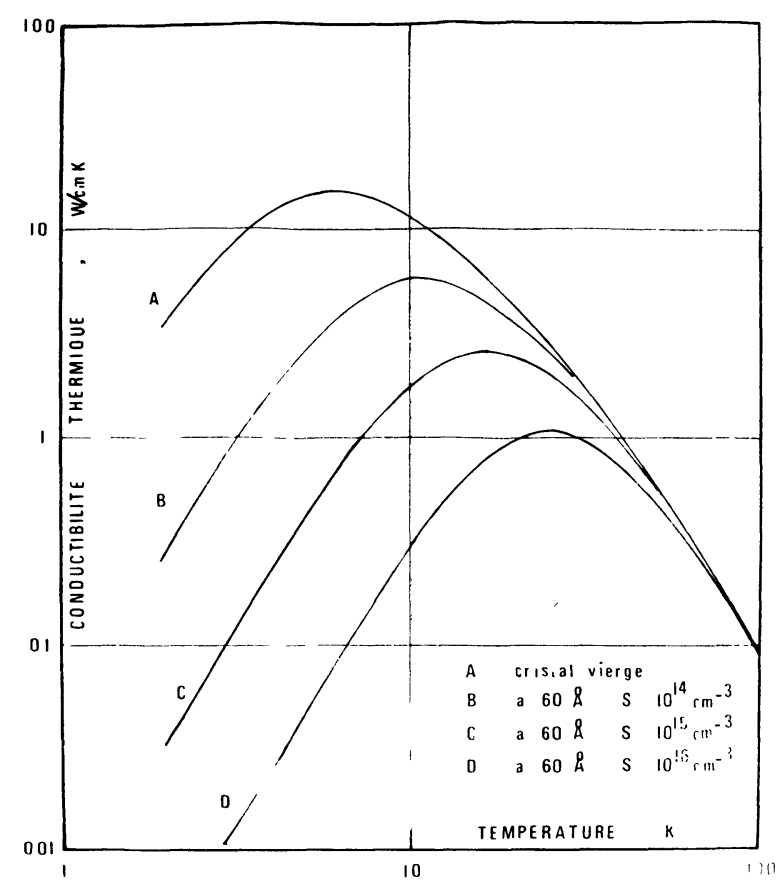

FIG. 3. - Influence of precipitate concentration on thermal conductivity of $\mathrm{CdTe}$ (Theoretical curve calculated with Callaway model).

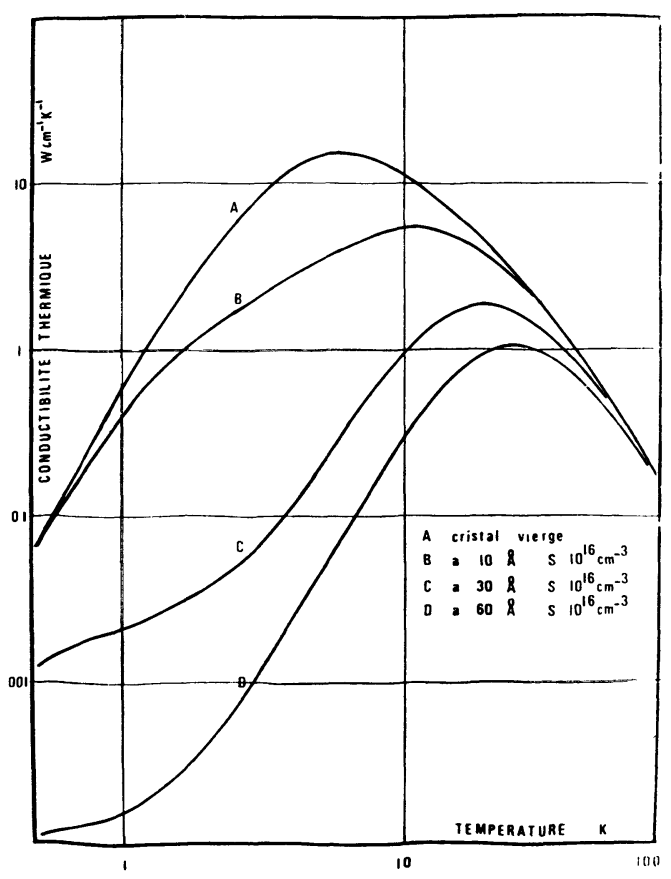

FIG. 4. - Influence of precipitate diameter on thermal conductivity of CdTe (Theoretical curve calculated with Callaway model).
The different temperature dependences of such scattering processes allow to fit theoretical curves with the experimental data. The determination of the anharmonic parameter $B$, which is constant for a given material, is performed by fitting the thermal conductivity data of a pure specimen at a temperature of about $40 \mathrm{~K}-50 \mathrm{~K}$.

We have drawn calculated thermal conductivity curves showing the successive contributions of the different parameters :

- precipitate concentration (Fig. 3),

- diameter of spherical precipitates (Fig. 4).

In these figures, the parameters $A, B$ and $L^{\prime}$ were kept constant.

3.2 FitTing DATA. - Table I summarizes all the geometrical characteristics and fitting values of the samples of both groups. The fitting of the experimental results with Callaway's model leads to a large point defect concentration always higher than $10^{18} \mathrm{~cm}^{-3}$. Only the purest samples of each group result in a lower one. The experimental data show also the existence of microprecipitates in all the specimens whatever their elaboration techniques are. The microprecipitates have a diameter of about $100 \AA$ or more, and a concentration which can vary from $7 \times 10^{13} \mathrm{~cm}^{-3}$ (sample 39.3 ) to $1.8 \times 10^{14} \mathrm{~cm}^{-3}$ (sample 70.1).

4. Discussion. - 4.1 PoINT DEFECTs. - Cadmium and Tellurium which have many isotopes can explain a part of the high point defect concentration. Using equations [5] and [7] the calculation of the point defect parameter gives : $\Gamma(\mathrm{Cd})=2.27 \times 10^{-5}$ mole fraction, $\Gamma(\mathrm{Te})=2.36 \times 10^{-5}$ mole fraction, and for the compound : $\rightarrow \Gamma(\mathrm{CdTe})=2.36 \times 10^{-5}$ mole fraction. The coefficient $A$ is calculated from expression [4] : $A=9.44 \times 10^{-44} \mathrm{~s}^{3}$.

So the point defect concentration due to the isotopes of Tellurium and Cadmium is about $7 \times 10^{17} \mathrm{~cm}^{-3}$, which can be considered as the lowest possible point defect concentration in CdTe. The higher values measured can be explained by :

- Cadmium or Tellurium vacancies,

- impurities or doping element atoms, if they don't precipitate.

4.2 Precipitates. - The chemical nature of microprecipitates cannot be determined by our method. However their presence can be related to the growth process and the thermal treatment involved in it. We know that the lack of stability at the growth interface can induce perturbation of the solid phase [1] which can lead to :

- precipitation of a second phase,

- cellular or dentritic, instead of single, crystal growth. 
TABLE I

\begin{tabular}{|c|c|c|c|c|c|c|c|c|c|}
\hline \multirow[b]{2}{*}{ Group } & \multirow[b]{2}{*}{$\mathbf{N}^{\circ}$} & \multirow[b]{2}{*}{ Elaboration } & \multirow[b]{2}{*}{$\begin{array}{l}\text { Doping } \\
\text { parameter }\end{array}$} & \multicolumn{2}{|c|}{ Callaway model fit } & \multicolumn{3}{|c|}{ Geometrical parameter } & \multirow[b]{2}{*}{ Origin } \\
\hline & & & & $\begin{array}{c}\text { Point defect } \\
\text { concentration } \\
\mathrm{cm}^{-3}\end{array}$ & $\begin{array}{r}\text { Pre } \\
\underset{\AA}{\text { Diameter }}\end{array}$ & $\underset{\mathrm{cm}}{\text { Length } L}$ & $\begin{array}{c}L / S \\
\mathrm{~cm}^{-1}\end{array}$ & $\begin{array}{l}\text { Casimir } \\
\text { length } \\
\mathrm{cm}\end{array}$ & \\
\hline \multirow{5}{*}{1} & \multirow{2}{*}{ CTZ V13 } & \multirow{2}{*}{$\frac{\begin{array}{c}\text { Vertical } \\
\text { zone melt. }\end{array}}{-\begin{array}{c}\text { Idem }+ \\
\text { annealing }\end{array}}$} & \multirow{2}{*}{ Pure } & $9.4 \times 10^{17}$ & 108 & 0.51 & 5.7 & 0.34 & A \\
\hline & & & & $2.8 \times 10^{18}$ & 82 & 0.51 & 5.7 & 0.34 & A \\
\hline & CTI 79 & \multirow{3}{*}{$\begin{array}{c}\text { Modified } \\
\text { Bridgmann } \\
\text { tech. }\end{array}$} & $3 \times 10^{18} \mathrm{~cm}^{-3}$ & $2 \times 10^{18}$ & 100 & 0.61 & 6.6 & 0.34 & A \\
\hline & 13943 & & $\begin{array}{c}\text { Indium } \\
10^{17} \mathrm{~cm}^{-3}\end{array}$ & $1.6 \times 10^{18}$ & 100 & 0.68 & 4.5 & 0.44 & A \\
\hline & CTC 75 & & $\begin{array}{l}\text { Chlorine } \\
2.3 \times 10^{18} \mathrm{~cm}^{-3}\end{array}$ & $1.1 \times 10^{18}$ & 100 & 0.66 & 6.7 & 0.35 & A \\
\hline \multirow{6}{*}{2} & 393 & $\begin{array}{l}\text { Double } \\
\text { T. H. M. }\end{array}$ & Pure & $9.4 \times 10^{17}$ & 100 & 0.71 & 11.3 & 0.28 & B \\
\hline & 695 & \multirow{4}{*}{$\begin{array}{c}\text { T. H. M. } \\
\text { at } \\
750^{\circ} \mathrm{C}\end{array}$} & $\begin{array}{c}\text { Chlorine } \\
2 \times 10^{18} \mathrm{~cm}^{-3}\end{array}$ & $8.2 \times 10^{17}$ & 100 & 0.69 & 11.1 & 0.28 & B \\
\hline & 701 & & $\begin{array}{l}\text { Chlorine } \\
6.5 \times 10^{18} \mathrm{~cm}^{-3}\end{array}$ & $1.6 \times 10^{18}$ & 100 & 0.70 & 7.4 & 0.34 & B \\
\hline & 702 & & Idem & $2 \times 10^{18}$ & 100 & 0.73 & 7.8 & 0.35 & B \\
\hline & 703 & & Idem & $2 \times 10^{18}$ & 100 & 0.76 & 7.9 & 0.35 & B \\
\hline & 1148 & $\mid \begin{array}{c}\text { T. H. M. at } \\
900^{\circ} \mathrm{C}\end{array}$ & Chlorine & $1.1 \times 10^{18}$ & 100 & 0.60 & 6.5 & 0.34 & C \\
\hline
\end{tabular}
A : C. N. R. S. Bellevue
B : L. E. P. ;
C: C. R. N. Strasbourg.

Using infrared microscopy, many investigators have reported of macroscopic $(\geqslant 1 \mu \mathrm{m})$ absorbing regions in $\mathrm{CdTe}$ and subsequently proposed void or precipitates models related to crystal growth and post anneal conditions [12, 13]. However, the absence of precipitates visualised by that technique does not insure that material is of high quality. $\mathrm{X}$-ray reflection topography has been performed on specimens of the first group (CTZ, V 13, CTI 79, CTC 75) in order to determine the existence or not
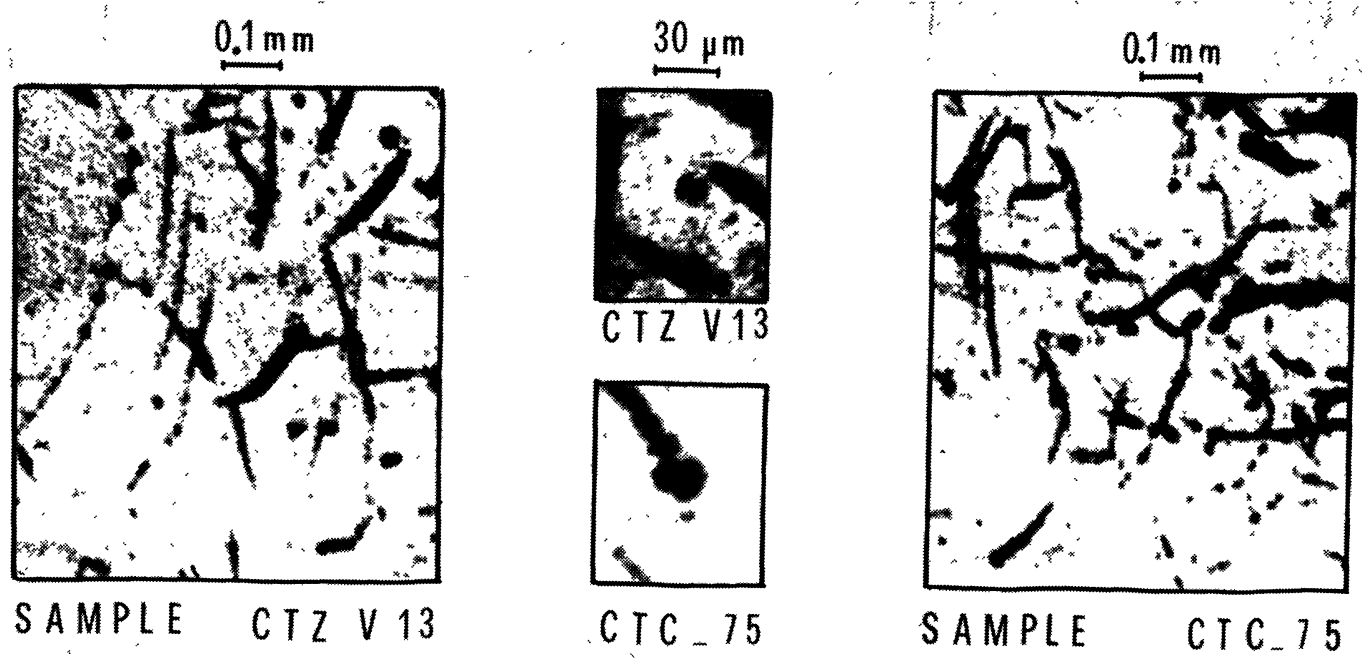

FIG. 5. - X-rays topographies of different samples of CdTe reflexion [110], $\lambda \mathrm{K} \alpha \mathrm{Mo}: 5 a$ : sample $\mathrm{n}^{\circ} \mathrm{CTZ}$ V13 (magnification: 80); $5 b$ : sample $\mathrm{n}^{\circ}$ CTC 75 (magnification: 80); 5c: image of precipitate aggregates in CTZ V13 and CTC 75 (magnification : 300). 
of such macroinhomogeneities. We can observe on these topographies (Fig. $5 a$ and $5 b$ ) two kinds of defects :

- dislocations with a density of $10^{4} \mathrm{~cm}^{-2}$ calculated by the Smith and Guttman method [14],

- precipitates of large diameter $(\geqslant 1 \mu \mathrm{m})$ which appear on certain dislocations. At high magnification (Fig. 5c) the observations show a black spherical spot separated in two equal parts by a contrasting bright line. This can be interpreted as large precipitates or precipitates agglomerates. Such defects have been encountered in Silicium [15], Cadmium Sulphide [16] an diamond [17] for impurity precipitates.

5. Origins of precipitates. - The origin of precipitation may be extrinsic: foreign atoms whose solubility limit is exceeded at the lower temperatures, or intrinsic : retrograde solubility shape of the CdTe solidus. Both processes can also occur together.

5.1 Precipitation OF FOREIGN ATOMS. - Precipitation of doping elements can be expected since data in table I show that the point defect concentration is always lower than the known quantity of doping element included in CdTe during elaboration. Only sample 1394-2 has a doping concentration of about $10^{17}$ Indium atoms per $\mathrm{cm}^{3}$ and a point defect concentration of about $1.6 \times 10^{18} \mathrm{~cm}^{-3}$. On the other hand precipitation of impurities is easy in CdTe because of the large concentration of Cadmium vacancies which allows CdTe to receive many foreign atoms. Kiseleva and al. [18] have found concentrations up to $10^{20}$ defects per $\mathrm{cm}^{3}$ which could be Cadmium vacancies. This concentration was estimated from the difference of $\mathrm{Te}_{2}$ vapour pressure over stoichiometric and non stoichiometric CdTe, and by microdensity measurements. We can notice these techniques are not electrical measurements. Measurements of the concentration of the different kinds of impurities were performed on specimens similar to CTZ V 13 by Triboulet and al. [19]. About one atomic ppm of $\mathrm{Si}, \mathrm{Ca}, \mathrm{Mg}, \mathrm{Al}, \mathrm{Na}, \mathrm{Cl}$, $\mathrm{F}$, $\mathrm{Co}$ and $\mathrm{Fe}$, were found. A large concentration of Carbon (a few tens ppm) was also found, which may come from the graphite coating of the inner surface of the synthesis quartz tube. Impurity concentrations of about $1 \mathrm{ppm}$ are shown by several investigations [20, 21]. Considering the impurity segregation coefficient values in CdTe (generally ranging between 0.2 to 0.5 , but more than 1 for Aluminium) and electrical measurements, Triboulet suggested [19] that impurities assemble to form highly compensated micro-inhomogeneities. That hypothesis seems to be confirmed by the microprecipitates we find in CTZ V 13 from thermal conductivity data.

5.2 Tellerium AND CADMiUm PRecipitation. In all cases the volume of the precipitates is greater than the foreign atoms content. Therefore precipitation of excess Tellurium can be considered because of the higher volatility of Cadmium. Electrical measurements indicate that the solidus in CdTe diagram is retrograde. For example, in samples pulled by THM at $700^{\circ} \mathrm{C}$, a decrease of five orders of magnitude of the Tellurium solubility occurs during the cooling to room temperature [20].

The existence of these microprecipitation processes is now confirmed by Magee and al. [22] with Transmission Electron Microscopy observations. It has been shown that many of the macroscopics defects observed in infrared microscopy are composed of aggregation of :

- Tellurium precipitates.

- $\mathrm{In}_{2} \mathrm{Te}_{3}$ or $\mathrm{CdCl}_{2}$ platelets in the case of Indium or chlorine doped samples.

- Dislocations.

- Stacking-faults.

5.3 Thermal treatment. - Magee and al. [22] have shown that annealing at temperatures over $500^{\circ} \mathrm{C}$ decomposes only Tellurium precipitates. In order to determine the precipitation mechanism, we have annealed at $580 \mathrm{C}$ during $18 \mathrm{~h}$, in a silica tube sealed under $10^{-5}$ torr, a specimen refined by vertical zone melting technique. Thermal conductivity data (Fig. 6) after annealing show a great increase in

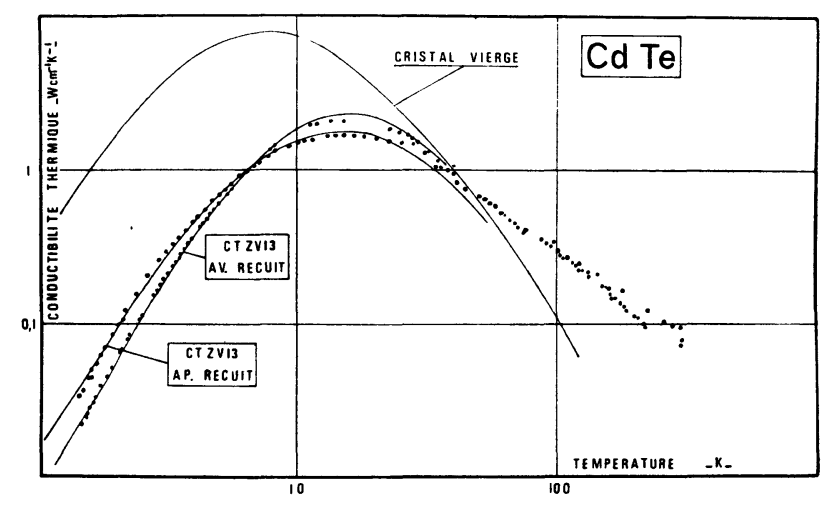

FIG. 6. - Thermal conductivity before and after annealing of a sample refined by vertical zone melting technique.

point defect concentration from $9.4 \times 10^{17} \mathrm{~cm}^{-3}$ to $2.8 \times 10^{18} \mathrm{~cm}^{-3}$, and a decrease in precipitates diameter from $108 \AA$ to $82 \AA$ (best fit values). If we suppose that Tellurium moves through the lattice in Tellurium position, we can evaluate the number of atoms which disperse in the lattice when the precipitate volume decreases. This dispersion of Tellurium corresponds to an increase in point defect concentration since an excess of Tellurium can be interpreted as Cadmium vacancies. The decrease of the precipitate volume is :

$$
\begin{aligned}
V_{\mathrm{p}} & =C\left(D_{1}^{2}-D_{2}^{2}\right) \frac{\pi}{6} \\
& =5.6 \times 10^{19} \AA^{3} \mathrm{~cm}^{-3}
\end{aligned}
$$


where $C$ is the precipitate concentration, $D_{1}$ and $D_{2}$ are the initial and final diameters of the precipitates. With an average volume of $34 \AA^{3}$ per atom [2] $V_{\mathrm{p}}$ can be associated to an increase of $1.6 \times 10^{18} \mathrm{~cm}^{-3}$ in point defect concentration which varies from $9.4 \times 10^{17} \mathrm{~cm}^{-3}$ to $2.6 \times 10^{18} \mathrm{~cm}^{-3}$ if all Tellurium atoms stay on lattice sites.

The Callaway model applied to our thermal conductivity measurement leads to a value of $2.8 \times 10^{18} \mathrm{~cm}^{-3}$ which is in very good agreement with the preceeding evaluation. This implies low contamination by impurity diffusion from the quartz during annealing.

6. Conclusions. - This investigation which agrees with Magee and al. [22] shows the presence in all specimens of microprecipitates of about $100 \AA$ of diameter. However X-ray topography shows that some precipitates can aggregate into macroscopic defects $(\geqslant 1 \mu \mathrm{m})$. The different elaboration methods seem to have reached a limiting value of purity depending of a contamination-purification equilibrium [19]. The research for increasing the quality of CdTe requires additonal investigations to determine the behaviour of microdefects after thermal annealing shedules [22].

Acknowledgements. - The authors wish to acknowledge R. Triboulet and Y. Marfaing for the supply of crystals grown by vertical zone melting technique and by Modified Bridgmann Method, C. Belin and A. Cornet for providing samples grown in Tellurium solution and C. Mai for X-ray topographs.

\section{References}

[1] Holland, M. G., Phys. Rev. 134 (1964).

[2] Slack, G. A., Galginaitis, S., Phys. Rev. 133 (1964).

[3] Slack, G. A., Phys. Rev. 6 (1972) 10.

[4] Vuillermoz, P. L., Pinard, P., Davoine, F., Revue Phys. Appl. 3 (1968) 11.

[5] Vuillermoz, P. L., Pinard, P., C. R. Hebd. Sean. Acad. Sci. Paris 269 (1969) 1193.

[6] Vuillermoz, P. L., Thèse, Lyon (1973).

[7] Callaway, J., Phys. Rev. 113 (1959) 1046.

[8] Nettleton, R. E., Phys. Rev. 132 (1963) 2032.

[9] Berman, R., Brock, J. C. F., Proc. R. Soc. A 289 (1965).

[10] Klemens, P. G., Proc. Phys. Soc. 68 (1955) 1113.

[11] Kyle, N. R., Proc. Intern. Symp. on CdTe (P. Siffert, A. Cornet Editors, Strasbourg) 1971.

[12] ZANIO, K., Proc. Intern. Symp. on CdTe (P. Siffert, A. Cornet Editors, Strasbourg) 1971.
[13] Bell, P. O., Wald, F., Proc. Intern. Symp. on CdTe (P. Siffert, A. Cornet Editors, Strasbourg) 1971

[14] Smith, C. S., Gutrman, L., Trans. AIME 197 (1953) 81.

[15] Fvrusho, K., Japan, J. Appl. Phys. 5 (1964).

[16] Chikawa, J., Appl. Phys. Lett. 4 (1964) 25.

[17] LANG, A. R., SHAH, C. J., Mineral Magazine 33 (1963) 594.

[18] Kiseleva, K. V., Klevkov, U. V., Maximovsky, S. N., Medvedev, S. A., Senturina, N. N., Proc. Intern. Symp. on CdTe (P. Siffert, A. Cornet Editors, Strasbourg) 1971.

[19] Triboulet, R., Marfaing, Y., Jour. Electrochem. Soc. 120 (1973) 9.

[20] CoRnet, A., Thèse, Strasbourg (1976).

[21] Schaub, B., Potard, L., Proc. Intern. Symp. on CdTe (P. Siffert, A. Cornet Editors, Strasbourg) 1971.

[22] Magee, T. J., Peng, J., Bean, J., Phys. Stat. Sol. (a) 27 (1975) 557. 